\title{
Antibiotic Activity of Streptomyces Isolates Collected From Soil of Kogi Central, Nigeria
}

\author{
Bello E.Kizito*1., Nwankwo E.O. \\ ${ }^{1}$ Kogi State University, P.M.B 1008, Faculty of Natural Sciences, Department of Microbiology, Anyigba, Kogi \\ State, Nigeria,
}

\begin{abstract}
A total of 62 Streptomyces were isolated from the farm land and waste land of Kogi central and screened for their antimicrobial activities. They were evaluated for their antagonistic activities on seven test organisms. Eighteen Streptomyces isolates which exhibit antimicrobial activity against at least 5 of the test organisms were characterized by conventional methods. The cultural characteristic was then studied. The result indicates that 9 (nine) isolates were highly active against Gram-positive bacteria. 6(six) isolates were highly active against a fungus with a zone of inhibition greater than $>14 \mathrm{~mm}$ in diameter. Most of the isolates inhibited growth of the Gram negative bacteria tested. All the antibiotic producing Streptomyces were isolated at different location from agricultural and non-agricultural waste land. Eighteen isolates shows antimicrobial effect against six bacteria and a fungus. With these findings, it is suggestive that Kogi central soil and it environ is a good source to explore potent antibiotics against clinically resistant pathogens.
\end{abstract}

Keywords: Antimicrobial activity, Microorganism, Streptomyces, Drug resistance.

\section{Introduction}

Soil is a natural reservoir for microorganisms and their antimicrobial products (Dancer, 2004). Actinomycetesare Gram positive bacteria which comprise a group of branching unicellular microorganisms. Among Actinomycetes, the Streptomycetes are the dominant (Balagurunathan, 1992).Filamentous soil bacteria belonging to the genus Streptomycesare widely recognized as industrially important microorganisms because of their ability to produce many kinds of novel secondary metabolites including antibiotics (Williams et al.,1983A; Crandall \&Hamil, 1986; Williams et al., 1986; KornWendisch\&Kutzner, 1992), Of all known drugs 70\% have been isolated from Actinomycetes bacteria of which 75\% and 60\% are used in medicine and agriculture respectively (Miyadoh, 19937; Tanka \& Mura, 1993).

Serious infections caused by bacteria that have become resistant to commonly used antibiotics have become a major global healthcare problem in the 21st century (Alanis, 2005).For more than two decades, clinicians and public health officials have faced hospital acquired Methicillin-Resistant Stapylococcuaureus (MRSA) and Vancomycin resistant strains and many Bacteria strains, which also bears resistance to many antibiotics (Hiramatsu, 1998; Bozdoganet al., 2003; Chang et al., 22003).

However, certain undesirable side effects and the spread of pathogens with this new antimicrobial drug resistance emphasize the need for the development of other newer antimicrobial agents with activity against such organisms (Jevittet al., 2003; Meka\& Gold, 2004; Wenzel, 2004; Nathwani, 2005).

In the present study, the isolation and characterization as well as the inhibitory effects of local Streptomyces isolates tested against various clinical antibiotic resistant bacteria and yeast were reported.

\section{Soil samples}

\section{Material And Method}

Soil samples were collected from the different location of Kogi Central province from June to September 2012. Diverse habitats in different areas were selected for the isolation of Streptomycesstrains. These habitats include a Cassava farmland, a Cashew plantation, a Yam farmland, a Refuse dump site, and a Grass land (Table 1). The samples were taken from the depth of $20 \mathrm{~cm}$ after removing approximately $3 \mathrm{~cm}$ of the soil surface with an auger. The samples were placed in polyethylene bags, closed tightly and properly labeled with the date of collection. Twenty five soil samples were collected within these period (June, 2012 - September, 2012). The collected soil samples were air dried for 10 days and was then further examined.

\section{Isolation of pure culture of Streptomyces}

Sixty twoStreptomyces strains were isolated and obtained as pure culture by using standard microbiological method. From each soil sample, $20 \mathrm{~g}$ of dried soil was suspended in $180 \mathrm{~mL}$ sterile water, and successive serial dilutions were made by transferring $1 \mathrm{~mL}$ of aliquots to 2 nd test tube containing $9 \mathrm{~mL}$ of sterile water, and in this way dilutions up to $10^{-5}$ were prepared. Each time the contents were vortexed to form uniform suspension. An aliquot of $1 \mathrm{~mL}$ of each dilution was inoculated into a petri dish and was overlaid with modified 
Czepex-dox agar medium supplemented with cycloheximide $(30 \mu \mathrm{g} / \mathrm{mL})$. The inoculated plates were incubated at $28^{\circ} \mathrm{C}$ and monitored for 7 days. The colonies were carefully counted by visual observation under a colony counter and Colony Forming Unit (C.F.U) per gram of soil was determined. Plates that gave 70-100 colonies were chosen for further isolation in pure culture. Suitable colonies that showed Streptomyceslike appearance under light microscope were re-cultivated several times for purity. The purified Streptomyces were preserved on Czepex-dox agar at $4^{\circ} \mathrm{c}$.

\section{In vitro screening of isolates for antagonism}

Preliminary screening for antibiotic activity of the isolates was done by using streak-plating technique on agar medium. Plates were prepared and inoculated with Streptomyces isolate by a single streak of inoculum at the top end of the Petri dish. After 5 days of incubation at $28^{\circ} \mathrm{C}$, the plates were seeded with test organisms by a single streak perpendicular to theStreptomycesstrains. The microbial interactions were observed, analyzed by thezone of inhibition, measured to the nearest millimeter, after $24 \mathrm{~h}$ of incubation at $37^{\circ} \mathrm{C}$ (Madiganet al., 1997).

\section{Test organisms}

Three Gram positive bacteria (Streptococcus pyogen,Bacillus subtilis, Staphylococcus aureusATCC 25923) andthree Gram negative (Escherichia coli ATCC25922, Pseudomonas aeruginosaATCC27853,Shigelladysenteriae) Bacteria and one yeast (Candida albicanATCC1023) were used to determine the antimicrobial activity of the isolatedStreptomycesstrains. Theabove mentioned Bacteria were cultured in a Nutrient Agar (NA) (Difco) at $37 \pm 0.1^{\circ} \mathrm{C}$ for24hours and were maintained in Nutrient agar slant at $4^{\circ}$ C. C. albicanbeing cultured in aSabouraund Dextrose Agar (SDA) (Difco) at $28 \pm 0.1^{\circ} \mathrm{C}$ for 48 hours.

\section{Result And Discussion}

Soil samples were collected fromfarm land and waste land of Kogi central senatorial district, Nigeria. Soil samples was dried and takenfor isolationof Streptomyces. The suspected 62 Streptomyces were isolated from five different sample site location in which the 62 Streptomyces isolates were inoculate into a Czapedox agar medium slant at $4^{0} \mathrm{c}$. all the 62 culture were screened against bacteria but only the 18 isolatesshowed antimicrobial activity and were designated as G1, 2, 3, Y1, 2, 3, 4, C1, 2, 3, D1, 2, 3, 4, 5, CW1, 2, 3, 4, 5 (table 2). They were also studied for cultural characteristic (table 3).

This study was undertaken with the aim of isolating and screening of Streptomyces in Agricultural and non-agricultural soil of Kogi central, Nigeria and selecting the isolates with antibacterial activity. Using the modified Czapedox media and cultivation condition as described previously, a total of 62 different Streptomyces isolates were recovered from 25 soil samples that were collected from agricultural and non-agricultural soil of Kogi central, Nigeria.

The soil of wasteland (Refuse dump) at Ikuehi and Grassland gives a higher number of Streptomyces isolates (21 and 19 respectively) with respect to non-agricultural soil (table1). All isolates grew on Czapedox agar medium showing morphology typical to Streptomyces since the colonies were slow growingsince the colonies were slow growing, aerobic, chalky, heaped folded and with aerial and substrate (reverse) mycelia of different color (Table 3).

In addition, all colonies possess an earthy odor. Most of the species produce antibiotic against the seven test organisms as reflected by a zone of growth inhibition. All isolates were positive to Gram-reaction and has different sugar utilization potentials, among other biochemical test (table 4). The cultural characteristics (pigment production), morphological characteristic of the different Streptomyces isolates are presented in table 3. The color of the substrate mycelium and aerial mycelium were varied. During screening of these isolates for drug discovery many potentially interesting micro-organisms might be excluded due to their morphological similarities and suggestive biochemical behaviors.

In this study, the total number of isolated Streptomyces (62) were screened on Agar medium and the antimicrobial was observed in $18(29.03 \%$ ) of the isolates which appears promising (table 2), nine (9) isolates $(14.5 \%)$ has a high antimicrobial activity $(>14 \mathrm{~mm})$ against Gram-positive bacteria, $15(24.2 \%)$ isolates against Gram-negative bacteria and $6(9.7 \%)$ isolates has an antagonistic effect against a Fungus.

Most of the isolates have moderate antimicrobial activity $(9-13 \mathrm{~mm}$ zone of inhibition) to the test organisms, $15(24.2 \%)$ isolates against Gram positive, 14(22.6\%) against gram negative and 6(9.7\%) isolate against a fungus.

There was a significant difference in the zone of inhibition of the isolates against the test organisms. $3(4.84 \%)$ isolates has a very high activity $(>14 \mathrm{~mm})$ against Streptococcuspyogens, $2(3.23 \%)$ isolates has an antimicrobial acivity against Methylene ResistantStapylococcusaureus, 16(25.81\%) isolates antagonize Eschericha coli with zone of inhibition $>14 \mathrm{~mm}$. $4(6.45 \%)$ isolates has a very high activity $(>14 \mathrm{~mm})$ against Pseudomonasaeroginosa and 3(4.84\%) isolates were highly antagonistic ( $>14 \mathrm{~mm}$ zone of inhibition) against 
Shigellaboydi. 6(9.68\%) isolates has a very high activity against Candidaalbicans. Result of the present study also indicates that the higher number of Streptomyces was isolated from waste lands (Refuse dump) against bacteria and these Streptomyces can be useful for many applications, such as infectious disease and the production of new antibiotics.

Isolate from Grassland produces secondary metabolites that were broad spectrum antimicrobial agent. G2 and G3 were active against Gram-positive and Gram-negative but to a lesser degree of Gram negative. G1, G2 and G3 were all antifungal. The activity of G3 was highest on E. coli, Bacillussubtilis, Streptococcuspyogenand Candidaalbican.

Isolates from Yam farm land were majorly antibacterialisolates (fig 1). Y1 was a broad spectrum substance having inhibitory activity on the entire tested organism. The highest activity was on Bacillussubtilis, followed by Y2. Y3 and Y4 are limited to E. coli and Shigelladysenteriae respectively (fig 2).

The isolate from Cassava plant had broad spectrum activity against Shigelladysenteriae, Staphylococcus aureus, Pseudomonasaeroginosa,E.coli, and also C. albican (fig 3).

The isolate from isolates from refuse dump site also produces antimicrobial substance. All the isolates D1-D5 from refuse dump site produced antimicrobial substance with broad spectrum with activity against Streptococcus pyogen,E.coli,Bacillussubtilis,Shigelladysenteriae andCandidaalbican. They had broad spectrum activity to theorganisms listed in the latter sentence. But the most potent was D2, having the highest activity in thatcategory (fig 4).

Isolates from Cashew plantation had moderate to high activity against the indicator (test) organisms, two of the three isolates CW2 and CW3 had the highest activity against the test organisms (fig 5).

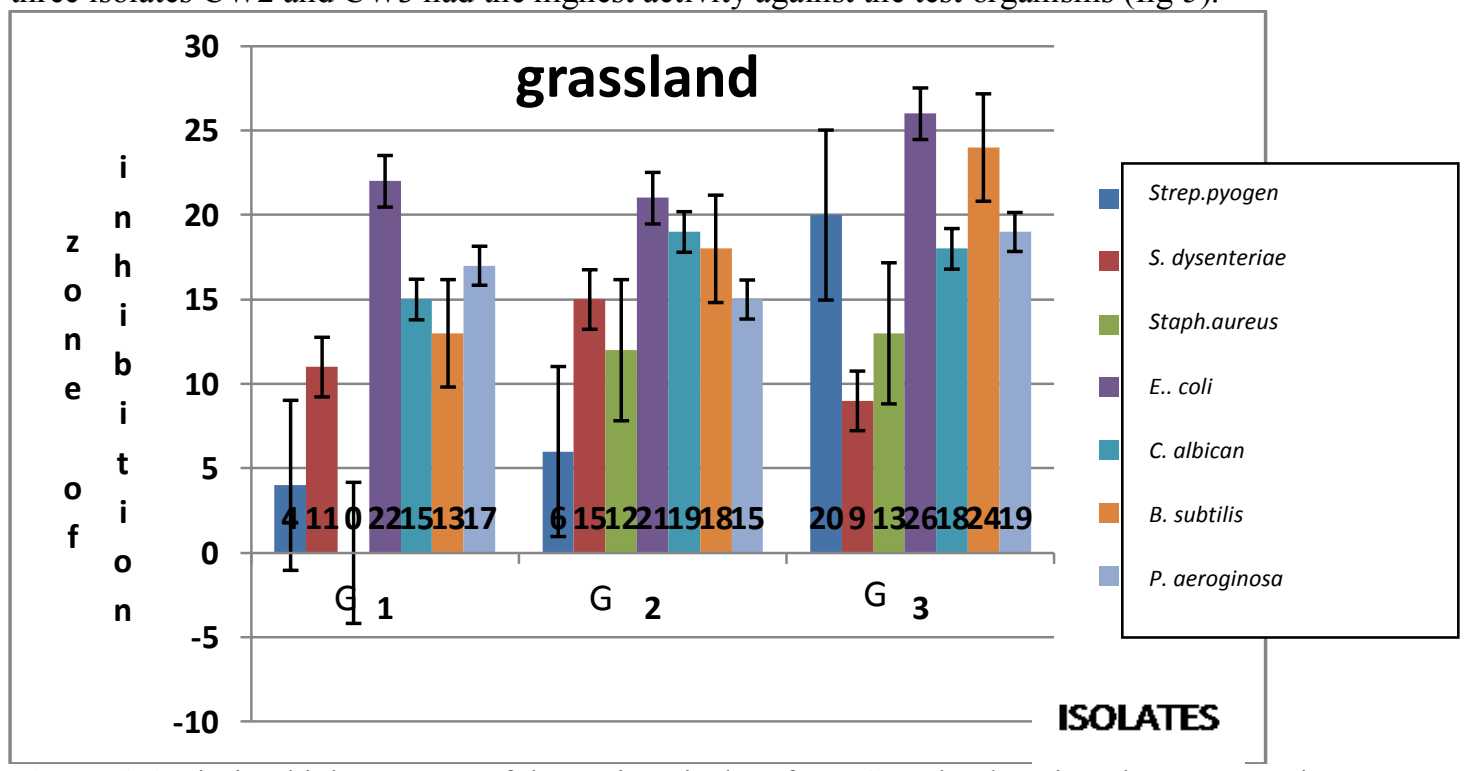

Figure 1 Antimicrobial spectrum of the various isolate from Grassland against the test organisms

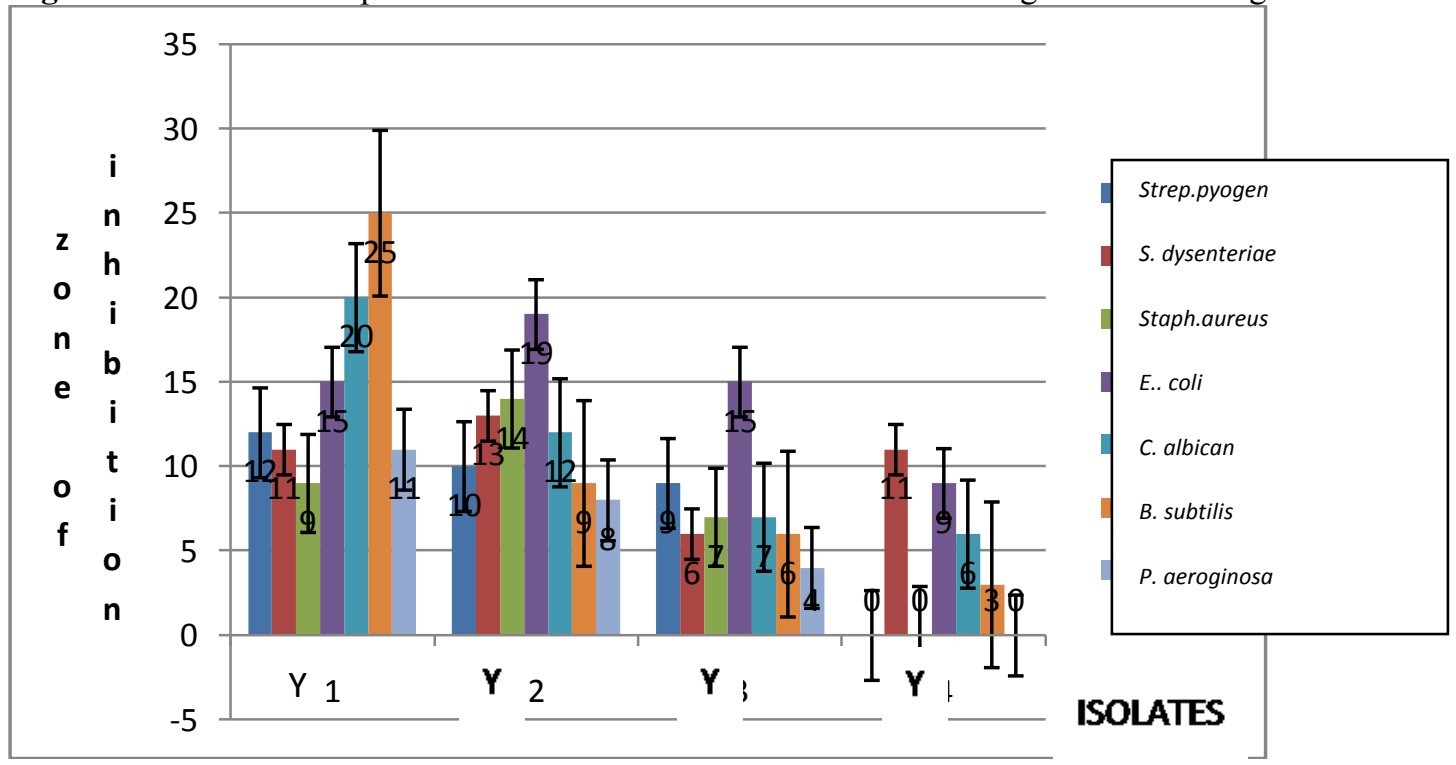

Figure 2 Antimicrobial spectrum of the various isolate from Yam Farmland against the test organisms 

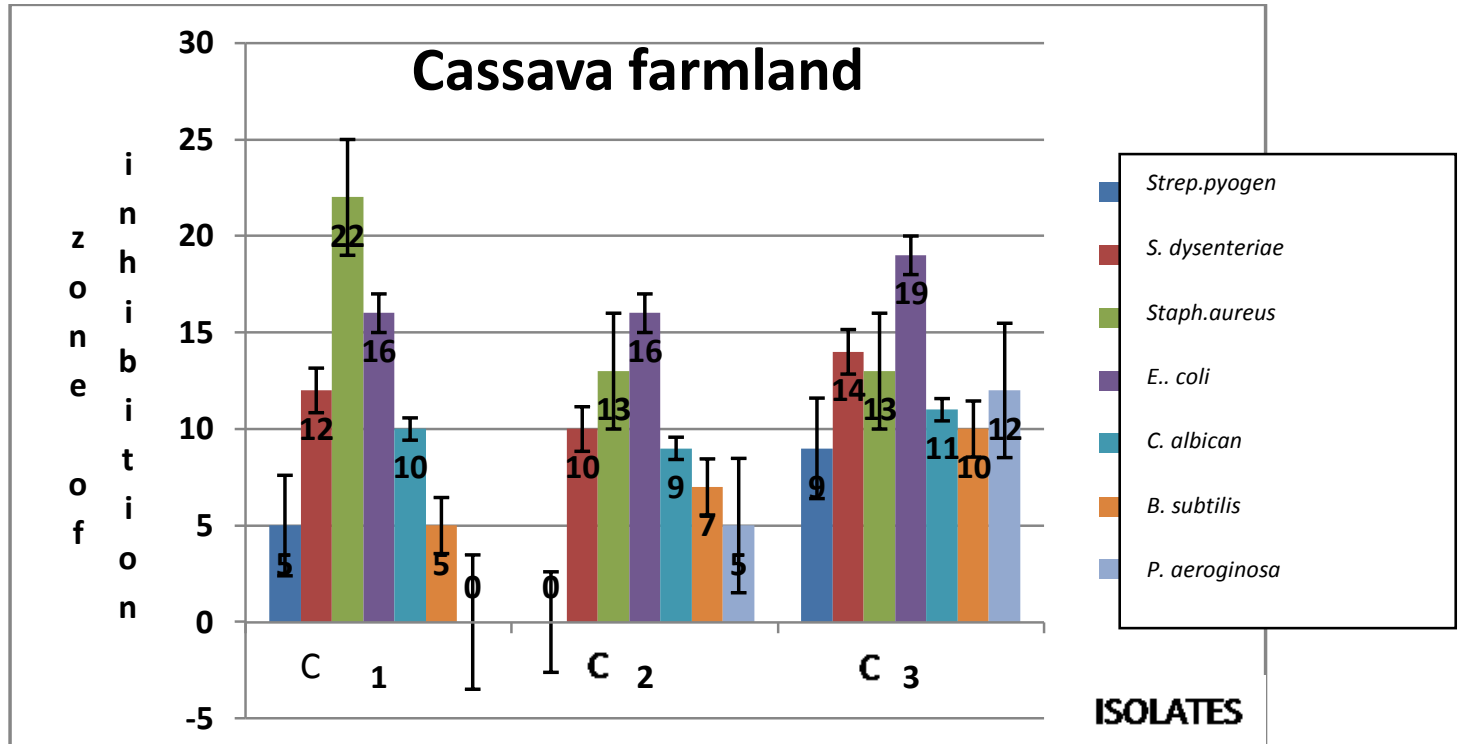

Figure 3 Antimicrobial spectrum of the various isolate from Cassava Farmland against the test organisms

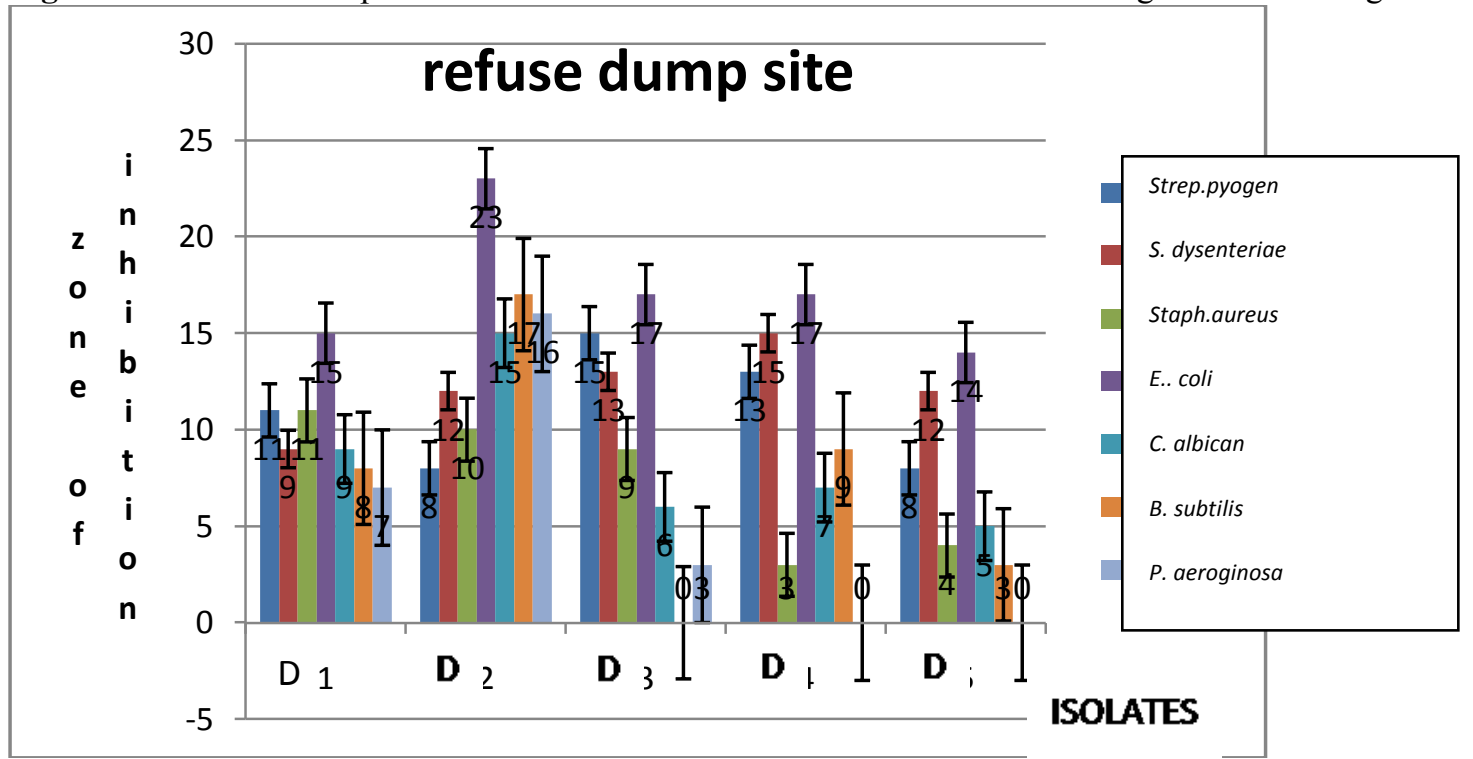

Figure 4Antimicrobial spectrum of the various isolate from Refuse Dump site against the test organisms

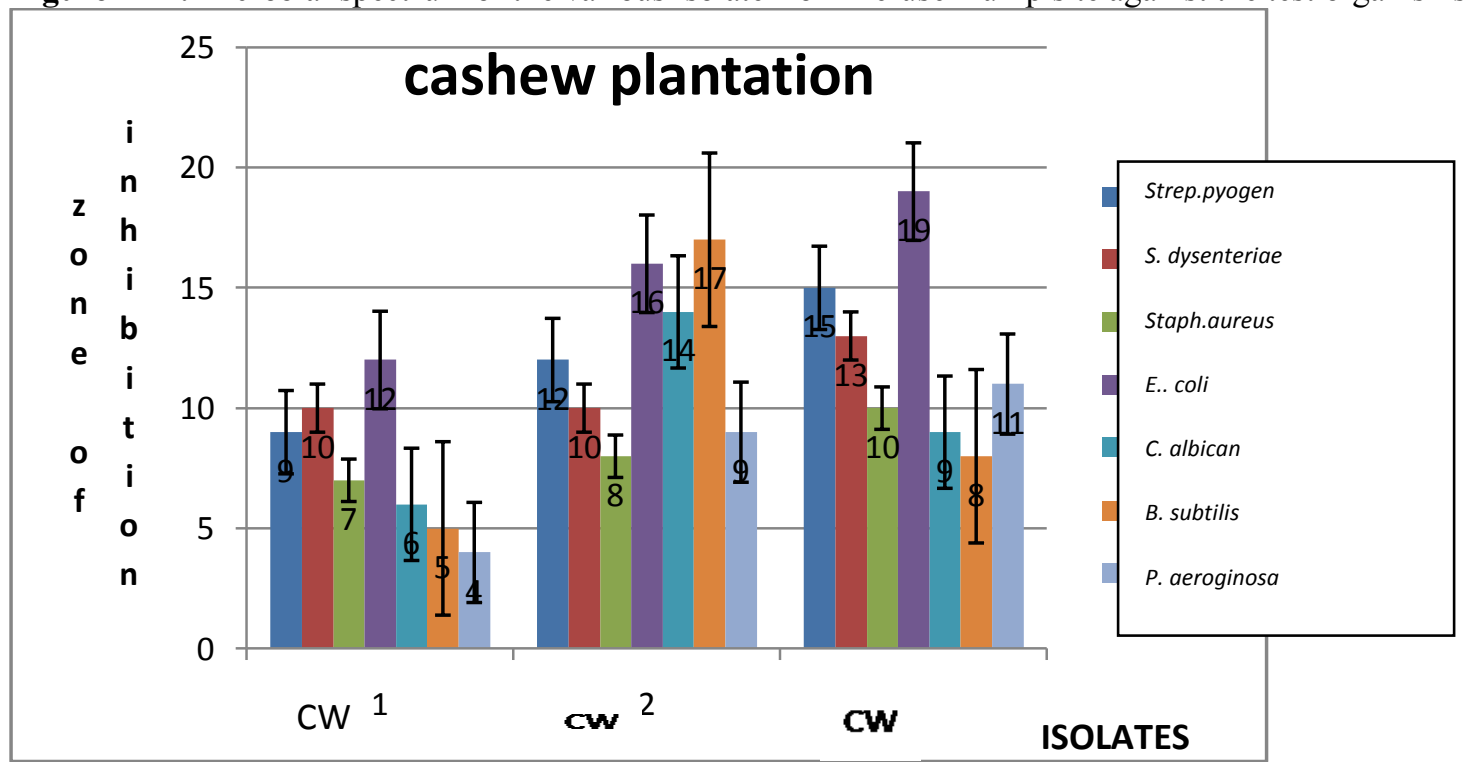

Figure 5 Antimicrobial spectrum of the various isolate from cashew plantation against the test organisms 
TABLE 1 Collection sites of soil samples and soil $\mathrm{pH}$

\begin{tabular}{|c|c|c|c|c|c|c|c|c|}
\hline $\begin{array}{l}\text { Date } \\
\text { collection }\end{array}$ & of & $\begin{array}{l}\text { Sample } \\
\text { pH }\end{array}$ & $\mathbf{A}$ & $\begin{array}{l}\text { Sample } \\
\text { pH }\end{array}$ & B & $\begin{array}{l}\text { Site } \\
\text { collection }\end{array}$ & $\begin{array}{l}\text { Number of Actinomycetes in } \\
\text { each grams } \\
\text { of soil (c.f.u/g) of dried } \\
\text { weight soil }\end{array}$ & Isolates \\
\hline $12-6-2012$ & & 6.7 & & 6.8 & & $\begin{array}{l}\text { Cashew } \\
\text { Farmland } \\
\text { Okene }\end{array}$ & $2.7 \times 10^{4}$ & CW $1-\mathrm{CW} 3$ \\
\hline $12-6-2012$ & & 7.4 & & 7.4 & & $\begin{array}{l}\text { Cassava } \\
\text { Farmland in } \\
\text { Ohueta }\end{array}$ & $4.0 \times 10^{8}$ & C $1-$ C 3 \\
\hline $10-7-2012$ & & 6.9 & & 6.8 & & $\begin{array}{l}\text { Yam Farmland } \\
\text { in Ogidi }\end{array}$ & $1.20 \times 10^{6}$ & $\mathrm{Y} 1-\mathrm{Y} 4$ \\
\hline $10-7-2012$ & & 7.0 & & 7.1 & & $\begin{array}{l}\text { Grassland in } \\
\text { Ihima }\end{array}$ & $1.37 \times 10^{6}$ & G 1-G 3 \\
\hline $11-7-2012$ & & 7.2 & & 7.3 & & $\begin{array}{l}\text { Refuse Dump in } \\
\text { Ikuehi }\end{array}$ & $2.3 \times 10^{5}$ & D 1---D 5 \\
\hline
\end{tabular}

Legend: $\mathrm{G}$-Grassland, Y-Yam farmland, C-Cassava farmland, D-Refuse-dump site, CW-Cashew plantation.

Table 2 The zone of inhibition of isolate to test organism to the nearest millimeter

\begin{tabular}{|c|c|c|c|c|c|c|c|}
\hline \multirow{2}{*}{$\begin{array}{l}\text { Isolat } \\
\text { es } \\
\text { Name }\end{array}$} & \multirow[b]{2}{*}{$\begin{array}{l}\text { Streptococuspyo } \\
\text { gen }\end{array}$} & \multicolumn{3}{|c|}{ Test organisms } & \multirow[b]{2}{*}{$\begin{array}{l}\text { Candidaalbi } \\
\text { can }\end{array}$} & \multirow[b]{2}{*}{$\begin{array}{l}\text { Bacillussubt } \\
\text { ilis }\end{array}$} & \multirow[b]{2}{*}{$\begin{array}{l}\text { Pseudomonasaerogi } \\
\text { nosa }\end{array}$} \\
\hline & & $\begin{array}{l}\text { Shigelladysente } \\
\text { riae }\end{array}$ & $\begin{array}{l}\text { Staphylococcusau } \\
\text { reus }\end{array}$ & $\begin{array}{l}\text { Escherichia } \\
\text { coli }\end{array}$ & & & \\
\hline$\overline{\mathrm{G} 1}$ & 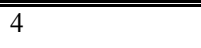 & 11 & "0 & 22 & 15 & 13 & 17 \\
\hline G 2 & 6 & 15 & 12 & 21 & 19 & 18 & 15 \\
\hline G 3 & 20 & 9 & 13 & 26 & 18 & 24 & 19 \\
\hline Y 1 & 12 & 11 & 9 & 15 & 20 & 25 & 11 \\
\hline Y2 & 10 & 13 & 14 & 19 & 12 & 9 & 8 \\
\hline Y 3 & 9 & 6 & 7 & 15 & 7 & 6 & 4 \\
\hline Y 4 & 0 & 11 & 0 & 9 & 6 & 3 & $\mathrm{O}$ \\
\hline $\mathrm{C} 1$ & 5 & 12 & 22 & 16 & 10 & 5 & 0 \\
\hline $\mathrm{C} 2$ & 0 & 10 & 13 & 16 & 9 & 7 & 5 \\
\hline $\mathrm{C} 3$ & 9 & 14 & 13 & 19 & 11 & 10 & 12 \\
\hline D 1 & 11 & 9 & 11 & 15 & 9 & 8 & 7 \\
\hline D 2 & 8 & 12 & 10 & 23 & 15 & 17 & 16 \\
\hline D 3 & 15 & 13 & 9 & 17 & 6 & 0 & 3 \\
\hline D 4 & 13 & 15 & 3 & 17 & 7 & 9 & 0 \\
\hline D5 & 8 & 12 & 4 & 14 & 5 & 3 & 0 \\
\hline CW1 & 9 & 10 & 7 & 12 & 6 & 5 & 4 \\
\hline CW 2 & 12 & 10 & 8 & 16 & 14 & 17 & 9 \\
\hline CW 3 & 15 & 13 & 10 & 19 & 9 & 8 & 11 \\
\hline
\end{tabular}

Legend: G -Grassland, Y-Yam farmland, C-Cassava farmland, D-Refuse-dump site, CW-Cashew plantation. 
Table 3 Microscopic and colonial morphological characteristics of isolates

\begin{tabular}{|c|c|c|c|c|c|c|c|}
\hline $\begin{array}{l}\text { Sample type, } \\
\text { isolate name }\end{array}$ & Appearance & $\begin{array}{l}\text { Elevati } \\
\text { on }\end{array}$ & $\begin{array}{l}\text { Arial } \\
\text { pigment }\end{array}$ & Edge & $\begin{array}{l}\text { Substrate } \\
\text { pigmentatio } \\
\text { n }\end{array}$ & $\begin{array}{l}\text { Spore } \\
\text { arrangement }\end{array}$ & $\begin{array}{l}\text { Visible diffusible } \\
\text { pigment }\end{array}$ \\
\hline Grassland & & & & & & & \\
\hline G 1 & $\begin{array}{l}\text { Dry and } \\
\text { smooth }\end{array}$ & $\begin{array}{l}\text { Conve } \\
\mathrm{x} \\
\end{array}$ & White & Fuzzy & Cream & Straight & Brown \\
\hline G 2 & $\begin{array}{l}\text { Dry, rough } \\
\text { granules }\end{array}$ & $\begin{array}{l}\text { Conve } \\
\mathrm{x} \\
\end{array}$ & Grey-black & $\begin{array}{l}\text { Irregul } \\
\text { ar }\end{array}$ & Grey & Spiral & - \\
\hline G 3 & $\begin{array}{l}\text { Dry and } \\
\text { smooth }\end{array}$ & $\begin{array}{l}\text { Conve } \\
\mathrm{x} \\
\end{array}$ & $\begin{array}{l}\text { Army } \\
\text { green }\end{array}$ & Entire & Dark brown & Spiral & Chocolate brown \\
\hline Yam Farm & & & & & & & \\
\hline Y 1 & $\begin{array}{l}\text { Dry and } \\
\text { smooth }\end{array}$ & $\begin{array}{l}\text { Conve } \\
\mathrm{x}\end{array}$ & $\begin{array}{l}\text { Creamy- } \\
\text { white }\end{array}$ & Fuzzy & Cream & Ret flexiblis & - \\
\hline Y 2 & $\begin{array}{l}\text { Dry and } \\
\text { smooth }\end{array}$ & $\begin{array}{l}\text { Conve } \\
\mathrm{x}\end{array}$ & $\begin{array}{l}\text { Brown } \\
\text { with white } \\
\text { edge }\end{array}$ & Entire & Brown & Spiral & - \\
\hline Y 3 & $\begin{array}{l}\text { Dry and } \\
\text { smooth }\end{array}$ & Flat & Grey & Entire & $\begin{array}{l}\text { Golden } \\
\text { yellow }\end{array}$ & Coiled spiral & - \\
\hline Y 4 & $\begin{array}{l}\text { Dry and } \\
\text { smooth }\end{array}$ & Flat & Grey & $\begin{array}{l}\text { Irregul } \\
\text { ar }\end{array}$ & $\begin{array}{l}\text { Golden } \\
\text { yellow }\end{array}$ & Straight & - \\
\hline Cassava Farm & Smooth, dry & & & & & & \\
\hline C 1 & Granules & $\begin{array}{l}\text { Conve } \\
\mathrm{x} \\
\end{array}$ & White & Fuzzy & $\begin{array}{l}\text { Golden } \\
\text { yellow }\end{array}$ & Spiral & - \\
\hline $\mathrm{C} 2$ & $\begin{array}{l}\text { Smooth, dry } \\
\text { granules }\end{array}$ & $\begin{array}{l}\text { Conve } \\
\mathrm{x} \\
\end{array}$ & White & Entire & Cream & Ret flexibilis & - \\
\hline C 3 & Rough and dry & $\begin{array}{l}\text { Conve } \\
\mathrm{x}\end{array}$ & $\begin{array}{l}\text { White, } \\
\text { later turns } \\
\text { green }\end{array}$ & $\begin{array}{l}\text { Irregul } \\
\text { ar }\end{array}$ & Yellow & Ret flexibilis & Oxblood \\
\hline $\begin{array}{l}\text { Refuse dump } \\
\text { D } 1\end{array}$ & $\begin{array}{l}\text { Smooth and } \\
\text { dry }\end{array}$ & $\begin{array}{l}\text { Conve } \\
\mathrm{x}\end{array}$ & White & Fuzzy & Yellow & Flexibilis & - \\
\hline D 2 & $\begin{array}{l}\text { Smooth, dry } \\
\text { and granular }\end{array}$ & $\begin{array}{l}\text { Conve } \\
\mathrm{x} \\
\end{array}$ & Orange & Entire & White & Ret flexibilis & - \\
\hline D 3 & $\begin{array}{l}\text { Dry, smooth } \\
\text { and granular }\end{array}$ & Flat & Brown & Entire & Brown & Coiled spiral & - \\
\hline D 4 & $\begin{array}{l}\text { Dry and } \\
\text { smooth }\end{array}$ & $\begin{array}{l}\text { Conve } \\
\mathrm{x} \\
\end{array}$ & $\begin{array}{l}\text { Chocolate } \\
\text { brown }\end{array}$ & Entire & Brown & Flexibilis & Brown \\
\hline D 5 & $\begin{array}{l}\text { Dry and } \\
\text { powdery }\end{array}$ & Flat & Black & $\begin{array}{l}\text { Circul } \\
\text { ar }\end{array}$ & Brown & Spiral & - \\
\hline $\begin{array}{l}\text { Cashew Farm } \\
\text { CW } 1\end{array}$ & $\begin{array}{l}\text { Dry and } \\
\text { smooth }\end{array}$ & $\begin{array}{l}\text { Conve } \\
\mathrm{x} \\
\end{array}$ & White & Fuzzy & Cream & Coiled spiral & - \\
\hline CW 2 & $\begin{array}{l}\text { Dry and } \\
\text { smooth }\end{array}$ & $\begin{array}{l}\text { Conve } \\
\mathrm{x} \\
\end{array}$ & Grey & $\begin{array}{l}\text { Irregul } \\
\text { ar }\end{array}$ & Grey & Ret flexibilis & - \\
\hline CW 3 & $\begin{array}{l}\text { Dry and } \\
\text { smooth }\end{array}$ & $\begin{array}{l}\text { Conve } \\
\mathrm{x}\end{array}$ & Cream & Entire & Cream & Spiral & - \\
\hline
\end{tabular}

Legend: G - Grassland, Y-Yam farmland, C-Cassava farmland, D-Refuse-dump site, CW-Cashew plantation, - (absent). 


\section{Conclusion}

Microorganisms of genus Streptomyces produce a wide spectrum of bioactive substances (antibiotics, pigments and enzymes) with application in pharmaceutical and food industries, in biotechnology and laboratory practice. The ability of Streptomyces to synthesize enzyme inhibitors reveals a new aspect of microbial Anmesalism (antagonism). The present work reveals that Streptomyces isolate G 3 shows the highest activity against Streptococcus pyogen, Staphylococcus aureus, Eschericha coli, Bacillus subtilis, Shigelladyseneriae, Pseudomonas aeroginosa and Candida albican. Although Streptomyces may be found in both cultivated and virgin soils, they are especially abundant under alkaline conditions and soil of high organic matter content (Sigrid et al., 2008). Morphological and biochemical properties of the promising isolates were found to be similar to those described by Ajijuret al., 2011, he described the existence of this organisms in the soil to be very important due to their roles in decomposing organic matters, and its ability to produce antibiotics. In this present study, presence of Streptomyces in the soil and their ability to produce secondary metabolites agreed with the previous findings and reports.

From this finding, I urge anyone/organization that is interested in discovery of wide spectrum antibiotic producing Streptomyces from soil to take a look at Kogi Central soil and itsFarmlands, it might be the best choice of all.

\section{Acknowledgement}

The Author wish to thank Prof. Mrs. L.E Odama for her helpful assistance in this work.

\section{References}

[1]. AJIJUR, R.-MOHAMMAD, Z.I.-ANWAR, U.L. 2011. Antibacterial activities of Streptomyces isolates collected from soils of Rajshahi, Bangladesh biotechnology research international Vol 2011, article ID 857925, 6 pagesDoi:10.4061/2011/857925.

[2]. ALANIS, A.J. 2005. Resistance to antibiotics: are we in the post-antibiotic era? Archives of Medical Research 36: 697-705.

[3]. BALAGURUNATHAN, R. 1992. Antagonistic actinomycetes from Indian willow seasediments with reference to $\alpha, \beta$ - unsaturated $\gamma$ - lactone type ofantibiotic from Streptomycesgriseobrunneus. Ph. D. Thesis, Annamalai University, India, pp 88.

[4]. BOZDOGAN, B.- ESEL, D.- WHITENER, C. 2003. Antibacterial susceptibility of a vancomycin-resistant Staphylococcus aureusstrain isolated at the Hershey Medical Center. Journal of Antimicrobial Chemotherapy52: 864-868.

[5]. CHANG, S.- SIEVERT, D.M.- HAGEMAN, J.C. 2003. Infection with vancomycin resistant Staphylococcus aureuscontaining the vanA resistance gene. The New England Journal of Medicine348: 1342-1347.

[6]. CRANDALL, L.W.- HAMIL, R.L. 1986. Antibiotics produced by Streptomyces: major structural classes. In: Queener SW, Day LE (eds), The bacteria, Vol. 9, Academic Press, Orlando, pp 355-401.

[7]. DANCER, S.J. 2004. How antibiotics can make us sick: the less obvious adverse effects of antimicrobial chemotherapy. The Lancet Infectious Diseases4: 611-619.

[8]. HIRAMATSU, K. 1998. Vancomycin resistance in Staphylococci. Accessed on $22^{\text {nd }}$ of February 2012. Drug Resist Updates 1: 135 150 .

[9]. JEVITT, L.A.- SMITH, A.J.- WILLIAMS, P.P.- RANEY, P.M.- MCGOWAN, J.E.- TENOVER, F.C. 2003. In vitro activities of daptomycin, linezolid, and quinupristin-dalfopristin against a challenge panel of Staphylococci and Enterococci, including vancomycin intermediate Staphylococcus aureusand vancomycin- resistant Enterococcus faecium. Microbial Drug Resistance9: 389-393.

[10]. KORN-WENDISCH, F.- KUTZNER, H.J. 1992. The family Streptomycetaceae. In: Balows A, Truper HG, Dworkin M, Harder W, Schleifer KH (eds), The prokaryotes, Springer-Verlag, New York, 921- 995.

[11]. MADIGAN, M.T.- MARTINKO, J.M.- PARKER, J. 1997. Antibiotics: isolation and characterization. In: Brock Biology of Microorganisms, 8th (ed), Prentice-Hall International Inc. New Jersey, 440-442.

[12]. MEKA, V.G.- GOLD, H.S. 2004. Antimicrobial resistance to linezolid. Clinical Infectious Diseases39: 1010-1015.

[13]. MIYADOH, S. 1993. Research on antibiotic screening in Japan over the last decade: A producing microorganisms approach. Actinomycetologica9: 100-106.

[14]. NATHWANI, D. 2005.Tigecycline: clinical evidence and formulary positioning. International Journal of Antimicrobial Agents25: 185-192.

[15]. SIGRID, H.- ESPEN, F.- KJELL, D. J.- ELENA I.- TROND, E. E.- SERGEY, B. Z. 2008.Characterization of Streptomycesspp. isolated from the seashores in the Trondheim Fjord, Norway. marine Drugs.,vol (6), 620-635

[16]. TANAKA, Y.T.- MURA, S.O. 1993. Agro active compounds of microbial origin. Annual Review of Microbiology47: 57-87.

[17]. WENZEL, R.P. 2004. The antibiotic pipeline- challenges, costs, and values. New England Journal of Medicine351: 523-526.

[18]. WILLIAMS, S.T.- GOODFELLOW, M.- ALDERSON, G.- WELLINGTON, E.M.H.- SNEATH, P.H.A.- SACKIN, M.J. 1983 A. Numerical classification of Streptomycesand related genera. Journal of General Microbiology129: 1743-1813.

[19]. WILLIAMS, S.T.- GOODFELLOW, M.- ALDERSON, G. 1989. Genus StreptomycesWaksman and Henrici 1943, In: Williams ST, Sharpe ME, Holt JG (eds.) Bergey's Manual of Systematic Bacteriology, Vol. 4, Williams and Wilkins, Baltimore, 2452-2492. 